https://doi.org/10.18485/iipe_response2covid19.2021.ch9

\title{
THE UNITED NATIONS COMBAT AGAINST COVID-19 - THE ALARM FOR THE SECURITY COUNCIL REFORM? ${ }^{1}$
}

\begin{abstract}
Jovana Blešić ${ }^{2}$
Abstract: In a year when the United Nations celebrated its $75^{\text {th }}$ anniversary, the whole world was struck by a pandemic caused by the COVID-19 disease. Having in mind the importance of this organization, and, specifically, the Security Council as one of its main bodies, this is a good opportunity to reflect on its work. The international community was surprised that it had to wait until the summer of 2020 to hear from this body. Resolution 2532 was adopted on July $1^{\text {st }}, 2020$ and, up to this day, it is the only resolution the Security Council devoted to COVID-19. This paper aims to analyse the weaknesses of the Security Council with regard to the UN combat in this time of crisis. To achieve that goal, the author researched the Resolution and its impact, given that the focal point of the Resolution was to stop conflicts around the world. The results demonstrate that perhaps the time has come for the long-awaited reforms.
\end{abstract}

Keywords: Security Council, COVID-19, Resolution 2532, United Nations, pandemic.

It is without a doubt that international organizations have established their role as a subject in public international law in the $21^{\text {st }}$ century. They serve as an instrument for accomplishing mutual interests between states (Blešić, 2020, p. 207). The United Nations (UN) system is perceived as one of the "most important historical moments in the progressive development of humanity" (Gordanić, 2015, p. 50). It was the accomplishment of dreams that many legal scholars and politicians had before the Second World War. When the UN Charter came to life, it settled the main bodies of

\footnotetext{
${ }^{1}$ The paper presents the findings of a study developed as a part of the research project "Serbia and challenges in international relations in 2021", financed by the Ministry of Education, Science, and Technological Development of the Republic of Serbia, and conducted by the Institute of International Politics and Economics, Belgrade.

${ }^{2}$ Research Associate, Institute of International Politics and Economics, Belgrade, jovana.blesic@diplomacy.bg.ac.rs.
} 
the United Nations. It would not be an exaggeration to say that the Security Council was, and still is, the most important organ due to its duties and competence. It is said in the Charter of the United Nations that the Security Council must maintain international peace and security, and it has the authority to act on behalf of all members of the United Nations. Chapter VI and Chapter VII are devoted to the competence of the Security Council. Chapter VI deals with the peaceful settlement of disputes so that it helps parties to achieve a solution without using force. On the other hand, Chapter VII provides power to the Security Council to impose enforcement measures. It is the only body in the UN system that has permanent and non-permanent members, and it was designed to be small so that it could be more successful in decision making. (Mingst, Karns, Lyon, 2017, pp. 34-37).

Even though this international organization began its work in times of peace, its greatest influence and power can be seen in times of crisis. But, in the year in which the United Nations marked its $75^{\text {th }}$ anniversary, the world was struck by a pandemic not yet seen. The COVID-19 pandemic made the whole world stop and brought insecurities to the international community. Many countries were, and many are still in lockdown. A great number of questions have been asked. Above all, why was the Security Council silent?

\section{RESOLUTION 2532 - THE SECURITY COUNCIL'S ANSWER TO COVID - 19}

When the name of the Security Council is mentioned, most people immediately think of world peace and security. And, truly, the UN Charter does impose those topics upon it. Article 24 is dedicated to the functions and powers of the Security Council, and it is said that the primary responsibility of this body is the maintenance of international peace and security (United Nations Charter, 1945). At the beginning of this paper, it should be brought up that the Security Council has shown an interest in topics other than those in its abundant history. For example, climate change. It could be the perfect example to show how the topic of international peace and security and related issues can be differently interpreted. In 2021, the Security Council did indeed discuss this topic, among others. Even in one of the Security Council reports, the question of whether climate change is a topic relevant to the competence of this body was asked. It was said that the potential consequences might be related to international peace and security and, therefore, this topic was discussed by the Security Council, especially given the fact that "international peace and security" are issues not specified in the charter itself, which leaves space for interpretation (Security Council Report, 2021, p. 1-3). Also, there is a broader perspective on the competence of the Security Council that arose from the concept of "human security" defined in one of the resolutions of the General Assembly as 
"an approach to assist the Member States in identifying and addressing widespread and cross-cutting challenges to the survival, livelihood, and dignity of their people" (Security Council Report, 2021, p. 4). The same argument may be used for the COVID-19 crisis. Some of the consequences of the latest crisis are visible, but most of them are still only in discussion. This health crisis has had and will have an influence on the economy, market, human rights, traffic, culture, sport, and perhaps every aspect of life. To be more precise, it may influence international combats and potential conflicts. Therefore, it is a question of international security, and the Security Council may pass a resolution on the matter.

When it comes to pandemics and health issues, this is not the first time that the world and the Security Council have had to face such a crisis. Global health has been a major topic on the agenda several times in the last two decades. First of all, in 2000, the Security Council imposed Resolution 1308 on the topic of HIV/AIDS. This resolution was adopted unanimously, and it was the first resolution in which the Security Council tackled this topic. It was also the first resolution in which the Security Council detected a health issue as a security threat. In the preamble, it was stressed how much the coordinated efforts of the member states and other United Nations organs, specifically the General Assembly and Secretary-General, are important in fighting this disease. The main part of the resolution was dedicated to the personnel of the peacekeeping missions. They ought to have proper education, protection, prevention, and counselling (Security Council, 2000). Then, in 2014, there was the Ebola outbreak in Africa. The focal point of Resolution 2177, adopted in 2014, was the situation in West Africa, in particular in Liberia, Guinea, Sierra Leone and Nigeria. The Security Council encouraged the governments of these countries to establish national mechanisms when it comes to dealing with Ebola but also to widen their politics on public health. Some paragraphs were dedicated to the sanctions and economic isolation of the mentioned countries and communication issues. The Resolution urged the member states to provide medical help and assistance and to implement the International Health Regulations from 2005. Finally, the World Health Organization (WHO) and Secretary-General ought to help and contribute to the fight against Ebola (Security Council, 2014).

The coronavirus outbreak, which happened on January $30^{\text {th }}, 2020$, was declared a public health emergency of international concern by the Director-General of the WHO. The global pandemic was declared by the World Health Organization on March $11^{\text {th }}$, 2020. The UN Secretary-General issued an urgent appeal for an immediate global ceasefire which received worldwide support on March $23^{\text {rd }}$. Successively, on April $9^{\text {th }}$, the Secretary-General addressed the Security Council to bring its attention to the significant threats to the maintenance of international peace and security posed by the COVID-19 pandemic, "potentially leading to an 
increase in social unrest and violence that would greatly undermine the world's ability to fight the disease". He pointed out eight risks that have emerged from this crisis. It is important to stress that the Secretary-General wrote in the letter that the engagement of the Security Council would be critical in maintaining peace and security and recalled the crucial role that the Security Council had in the HIV/AIDS crisis and the Ebola outbreak. He called for global and overall solidarity. (United Nations Secretary-General, 2020).

But it was not until July $1^{\text {st }}$ that the Security Council issued Resolution 2532. The delay was caused by a political disagreement between the United States of America and China about the language to be used in the resolution. The United States objected to any mentioning and endorsement of the WHO, as the former Trump administration criticised the way it dealt with the pandemic. In particular, the US mentioned "the charges against the Director-General of the WHO as being under China's control in the wake of the COVID-19 outbreak". Furthermore, the US used every opportunity to put China's responsibility in focus by calling the disease the "Wuhan virus" (Pavone, 2021, p. 2-3). On the other hand, China objected to the US proposal to include an open reference to state commitments to transparency and accountability in the management of the pandemic (Negri, 2021, p. 24). China tried to avoid any criticism of how it handled the first phase of the disease, specifically its lack of transparency and hiding information about COVID-19. The debate in the Security Council discussed how states could prevent human rights violations in emergency health responses, which showed that there had been a shift towards putting human rights at the centre of the global health crisis (Sekalala, Williams, Meier, 2021, p. 4). At the time of the adoption of Resolution 2532, the Security Council non-permanent members were Belgium, the Dominican Republic, Estonia, Germany, Indonesia, Niger, St. Vincent\&Grenadines, South Africa, Tunisia, and Vietnam. The resolution was drafted by France and Tunisia.

After reaffirming its role in maintaining international peace and security, the Security Council expressed its great concern given the impact of the COVID-19 pandemic across the globe, especially in countries with active armed conflicts, postconflict countries or in countries affected by the humanitarian crisis. In the preamble of the resolution, the Security Council recognized the key role of the United Nations in the COVID-19 crisis management when it comes to conflict-affected areas. In that sense, with the efforts made by the Secretary-General, Resolution 74/270 "Global solidarity to fight the coronavirus disease 2019 (COVID-19)" was adopted by the General Assembly in April 2020. This resolution manifested the intention of the General Assembly to show the importance of cooperation and its commitment to helping society in times of crisis such as this. It expressed optimism that the COVID19 pandemic and the current crisis could be overcome with the help of the United 
Nations system and cooperation between states. Another important document that was mentioned in the preamble was the Global Humanitarian Response Plan for COVID-19 by the United Nations. It is a public effort by the United Nations and its bodies and organizations and NGOs to give an adequate response to the pandemic and its humanitarian consequences (Security Council, 2020, preamble). This was the first time that the Security Council has called for a global ceasefire and humanitarian pause connected to a public and international health emergency, and this is where the significance of this resolution lies.

The operative part of the resolution consists of eight paragraphs. After demanding a general and immediate cessation of hostilities, the Security Council specifically called on all parties to an armed conflict to take a pause for at least 90 consecutive days. The goal was to enable the safe and sustained delivery of humanitarian assistance. The foundation for this call lies in the principles of humanity, neutrality, impartiality, and independence, but also in international humanitarian law and refugee law. It is important to note that this call does not apply to military operations against the Islamic State in Iraq and the Levant, Al Qaeda and Al Nusra Front, or anyone associated with them. The Security Council has three requests from the Secretary-General. First of all, the Secretary-General is asked to help ensure that all relevant parts of the United Nations system will accelerate their response to the COVID-19 pandemic, with an emphasis on countries in need. Secondly, he should provide updates to the Security Council on the efforts to address the pandemic in countries where armed conflicts take place or countries that are affected by the humanitarian crisis, but also updates on the impact on peacekeeping operations and Special Political Missions to deliver their priority tasks. Thirdly, the Secretary-General is requested to instruct peacekeeping operations to provide help to host country authorities in combating the pandemic and provide humanitarian access to internally displaced persons and refugee camps, and requests both the Secretary-General and the member states to take all steps to protect UN personnel in UN peace operations. Finally, the Security Council acknowledged the critical role that women played in COVID-19 response efforts and called for concrete actions to ensure the full and equal participation of women and youth in the development and implementation of an adequate and sustainable response to the pandemic (Security Council, 2020, para. 1-8).

Unlike the previous resolutions the Security Council adopted on the topic of public health, Resolution 2532 does not have any reference to the $\mathrm{WHO}$, and it recognizes the United Nations as the main and key actor in the global response to the pandemic. As we can see, the operative part of this Resolution is focused on humanitarian assistance and the Secretary-General's call for a global ceasefire. But if we compare this resolution to its precedents, when it comes to resolutions that 
demand ceasefires and encourage the peace process, Resolution 2532 "did not threaten the application of any enforcement measures on states or targeted sanctions on non-state actors involved in armed conflict for non-compliance with the Security Council's request" (Negri, 2021, p. 25). Also, due to the delay in the adoption of the Resolution, the practical effect of the combat cessation that was sought was minimal. An example of that is the Nagorno-Karabakh conflict, where the fighting has escalated since the ceasefire of 1994 (Pavone, 2021, p. 2). With the request for the Secretary-General to provide updates to the Security Council about the efforts to address the pandemic in countries where there are armed conflicts or that are affected by humanitarian crises, the Security Council created a formal mechanism for the Secretary-General to monitor or update the Security Council on the implementation of the ceasefire (Pavone, 2021, p. 4).

If we look back a year ago when the pandemic started, the eyes of the international community were pointed at the Security Council. Ever since the United Nations came into existence, this organ has been considered the most important one. This importance arises from the competence declared in Chapters VI and VII of the Charter of the United Nations. Therefore, the reaction was expected, and when it finally came, it did not satisfy the needs of the international community. The pandemic has revealed both the limits of the existing multilateral system and the cost of the failure of such a system (Patrick, 2020, p. 40). In 2020, China was holding the rotating presidency of the Security Council, and it used this opportunity to block the Security Council from considering any resolution about the pandemic, with the argument that public health matters do not fall under the Council's scope (Patrick, 2020, p. 44).

When it comes to the legal foundation of the Resolution, it is Article 36, para. 1 of the Charter of the United Nations, which gives power to the Security Council to adopt the recommendations in "a situation that might endanger peace and security". So, this document is in the form of a recommendation based on Chapter $\mathrm{VI}$ and, therefore, it is not binding on the parties (Pavone, 2021, pp. 4-5). The Security Council missed the opportunity to qualify COVID-19 as a threat to peace and security and missed framing it under Chapter VII, so it does not contain any enforcement measures. Therefore, these are the weaknesses of the Resolution. It is also important to remember that the UN Charter only gives the possibility for the United Nations to intervene. It does not impose any obligations (Blešić, 2020, p. 328). Despite the formal unanimity in its adoption, Resolution 2532 showed a background of sharp contrasts, rivalry amongst the permanent members and the predominance of domestic interests over the need for coordination. The secondary role of the Security Council in the pandemic is a symptom of the crisis of multilateralism and the current state of global health governance where 
international law is weak (Pavone, 2021, pp. 9-10). On the other hand, some authors believe that the Resolution can be binding, even under Chapter VI. Keeping in mind the circumstances of the Resolution's adoption, such an intent might have been pointed out. However, it was not made explicit, so it is unclear whether it is binding or not (Pobjie, 2020).

\section{THE UN RESPONSE TO COVID-19 - IS IT FINALLY TIME FOR THE REFORM?}

It is now a definite and well-known fact that the COVID-19 pandemic has caused a crisis with an impact that is yet to be seen. The question arises whether the world and the international community are ready to tackle it. Many authors propose the reform of the UN Security Council, especially in the light of today's circumstances. It is understood that it is one of the most difficult tasks. The humanitarian tragedies and unresolved conflicts in Syria, Yemen, and Libya show the need to open a dialogue to re-shape the Security Council (Caruso, 2020, p. 4).

The COVID-19 pandemic has put the United Nations to the test, and the global response to the pandemic has demonstrated weaknesses in the system regarding peace and security, sustainable socio-economic development and human rights (Özler, 2020, p. 445). The fact that effective action has not been seen in the face of the COVID-19 pandemic highlights institutional weaknesses in the United Nations Security Council (Özler, 2020, p. 448). Some authors believe that Resolution 2532 has brought new clarity about the reasons for the problem in the Security Council (O'Rourke, 2020, p. 324). For all of the above-mentioned reasons, the (neverending) discussion about reform has again been brought up.

In the previous decades, there have been many authors and many discussions about this topic. The focal point of this paper is not to discuss the specifics of the reform, but some of the proposals will be addressed. The veto power and the membership are two focal points when it comes to reforming. They have been discussed for several decades but without any significant solution yet.

"It goes without saying that all of us agree on the need to reform and enlarge the Security Council in all respects, in order for this vital United Nations organ to reflect the changes of the modern world... The difficulty is in deciding how this should be brought about... Collective human ingenuity created the United Nations in 1945. That ingenuity is still here and better informed than ever before. What is lacking today is political will." These are the words of Ambassador Gurirab of Namibia in his Opening Remarks as the President of the General Assembly at the Debate on Security Council Reform in 1999 (Kelly, 2000, p. 319).

There seems to be consent among the UN member states that the reform of the Security Council is required, but it is difficult to achieve agreement on specific 
options. When we take a look back at the establishment of the Security Council, it is important to remind ourselves that it is an organ that was designed with the task of preventing another war since the effects of the Second World War were still present at the time of its establishment. One important amendment was made in 1963 when the membership was changed. These changes were insufficient, and criticisms were leveled that the composition of the Security Council does not reflect the geopolitical, economic, and demographic picture of the current international community. But, it is important to keep in mind that finding the appropriate solution is one of the biggest challenges for the international community. The reform, if successful, could contribute to making the actions of the UN and its bodies more legitimate and effective in the future. (Hosli, Moody, O'Donovan, Kaniovski, Little, 2011, p. 165, 183).

The reform issue is not a new one. Back in 1950, Hans Kelsen identified the veto power as the probable cause of future challenges when it comes to the legitimacy of the Security Council (Mälkso, 2010, p. 94). It is important to mention the year 1963 when the first (and so far, the only) reform occurred. That year the Security Council membership increased from 11 to 15, and the voting majority changed from 7 to 9 . Ever since 1965, when this reform entered into force, the Security Council has not changed. Also, there are two sets of criticism, one relating to the efficiency of the Security Council and the other relating to the equity in the allocation of power that is or is not achieved (Gould \& Rablen, 2017, p. 146). When it comes to the later proposals for the Security Council's reform, they began in 1979, and those that were proposed in the 1980s usually pointed to the increase in the diversity and representation of the non-permanent members, while during the 1990s, it spread to the more diverse proposals (Kelly, 2000, p. 329). In the field of UN Security Council reform, it is worth mentioning that the General Assembly created the Open-ended working group on December $3^{\text {rd }}, 1993$. This group began to accomplish its task in 1994 by discussing questions such as existing suggestions about the expansion, making decisions in the Security Council, limitation and cancellation of the veto power, advancement of the work methods, and incorporation of non-permanent members. None of the many suggestions had adequate support (Gajić, 2015, p. 43).

The fact about which many authors agree is that the Security Council reflects the geopolitical reality of 1945 and not of today. Tharoor explains this argument in many ways. For example, mathematically, given the number of the member states of the Security Council in proportion to the number of the member states of the United Nations. Geographically, given the composition of the Security Council that represents the balance of power, it is no longer appropriate. Of course, politically, the five states that have permanent membership enjoy their status based on the 
victory won in the Second World War (Tharoor, 2011, pp. 397-398). To make any reform of the Security Council, it is necessary to make a change in the UN Charter, and any amendment requires a two-thirds majority of the overall UN membership. Then it would have to be ratified by two-thirds of the member states, which would usually require a parliamentary procedure. This is the case when it comes to structural reform, but working methods reform can be pursued without charter amendments because the Security Council has competence over its procedures. Therefore, the working method reform is perceived as a better solution, but not the best one. For example, the veto question is a structural one and cannot be changed without the charter amendment (Winther, 2020, p. 74). Structural reform is the most important one. One of the most mentioned changes concerns the allocation of seats to countries from the Global South and that the current permanent members have that privilege based on their victories in the Second World War. The discussions about Global North-South relations have an essential role in the debate about the reform (Winther, 2020, p. 93). There has been a critical perspective of developing countries on developed countries in a sense that institutional change can be used either to back up the principle of equality of states or to further undermine it, giving the opinion that there has been a competition between countries based on power and wealth (Mälkso, 2010, p. 101).

So, the Security Council has five permanent member states. These are the People's Republic of China, France, Russia, the United Kingdom of Great Britain and Northern Ireland, and the United States of America. Apart from having the permanent feature, these countries have veto power. This gives them the capability to prevent adaptation of any resolution, and it has caused many issues. The most important thing is that this veto power is in contradiction with Article 2 of the Charter, which proclaims the equality of the members. The essence of the Security Council is privilege over egalitarianism, said Mälkso (Mälkso, 2010, p. 97). It has also caused issues since the veto power has been used arbitrarily, and so one negative vote from one of these countries can prevail over all other votes. There has been a great deal of discussion about this power, and it is believed that "the five permanent members no longer represent the most stable and responsible United Nations members and that their veto power slows down and even prevents the most important decisions being made on matters of international peace and security" (Gordanić, 2015, p. 52). As we could see in the previous chapter of this paper, the rivalry between the great powers had once again resulted in adopting a resolution that was meant to be a compromise and therefore not as efficient. 


\section{CONCLUDING REMARKS}

The primary obstacles to the UN's reform are political above all. The biggest disagreements derive from the relations between strong and weak states. While everyone agrees that the United Nations is in need of reform, they do not agree on the course of the reform. One of the topics that they do have in common is the Security Council's reform. This topic is the most controversial, specifically when it comes to membership and voting rules in the Security Council. When it comes to membership, the consensus is that there is a need to augment the geographic representation, but it ought to be done so that the Security Council stays small in size and, therefore, efficient (Mingst, Karns, Lyon, 2017, pp. 56-57).

There has been a lot of commentary on whether 2020 will have transformative effects on world politics. Drezner pointed out years such as 1648, 1815, 1914, 1945, and 2008 as the years used for periodization in international relations. He asked a question about whether 2020 would be viewed as another point for periodization (Drezner, 2020, p. 18). It is inevitable that the COVID-19 pandemic will have its consequences on every part of our lives, including international relations, but will they be enough for the big reforms to arrive? When it comes to pandemics and international relations, the relationship is usually perceived as reciprocal. Most of the pandemics in the last century were short-term and did not have global effects, such as Ebola, SARS, or Zika. One of the reasons these diseases have not had a great influence on international relations must be the progress made in medicine and treatments (Drezner, 2020, p. 25).

Jubilees can influence international organizations as well. So, the year 2020 was not only the year of the COVID-19 pandemic but also the year in which the United Nations marked its $75^{\text {th }}$ anniversary. On that occasion, a global survey was conducted. It included more than 1.5 million people in 193 countries. The survey showed that our world is fragmented but also that the world is united regarding post-COVID recovery. Most people want better access to health care above all, and most of the respondents believe that international cooperation is the most important and look to the United Nations as a leader in addressing challenges in an effective way (Schlein, 2021). In January 2021, five new countries formally joined the Security Council. Those are India, Mexico, Norway, Ireland, and Kenya (AFP, 2021). As the Secretary-General of the United Nations pointed out in April 2020, the role of the Security Council in maintaining international peace and security was perceived as the most important one. That shows us the amount of trust that the Secretary-General put in this body. Nevertheless, just a couple of months later, we could see that maybe that trust was not justified. 
It is not unusual for the eyes of the international community to be focused on the United Nations. It often happens in times of crisis. Usually, states tend to take advantage of the moment, so reforms are suggested (Krivokapić, 2015, p. 10). Looking back at the previous times, most authors tend to be pessimistic when it comes to the Security Council's reform. There has been a chance for this to happen many times, but the bullet always misses. Many of them still believe that reform is unlikely to happen. But, what if the year 2020 has left some changes in the world? What if it has demonstrated how unpredictable everything is and that the world is indeed changing? Therefore, the door to reform should not be closed. The results of the mentioned survey can bring optimism. There is an old saying that even after the darkest night, the sun will rise again. For now, let us wait for that sun that is already breaking through and prepare to use the opportunity to reform.

\section{REFERENCES}

AFP - Agence France Presse (2021, January 4). Five New Countries Join Polarized UN Security Council, retrieved from https://www.barrons.com/news/fivenew-countries-join-polarized-un-security-council-01609780809. Accessed 21 May 2021.

Blešić, J. (2020). Odgovornost nedržavnih aktera [Responsibility of non-state actors], in: M. Vučić (Ed.), Nedržavni akteri u međunarodnom pravu [Non-state actors in international law] (pp. 319-343). Beograd, Institut za međunarodnu politiku i privredu.

Blešić, J. (2020). Venecijanska komisija - značaj i uloga [The Venice Commission significance and role], in: D. Čelić (Ed.), Pravna tradicija i integrativni procesi: zbornik radova [Legal tradition and integration processes : collection of papers] (pp. 207-222). Priština, tj. Kosovska Mitrovica, Pravni fakultet Univerziteta u Prištini sa privremenim sedištem u Kosovskoj Mitrovici.

Caruso, R. (2020). What Post COVID-19? Avoiding a "Twenty-first Century General Crisis". Peace Economics, Peace Science and Public Policy, 26(2), pp. 1-9. doi: https://doi.org/10.1515/peps-2020-9013.

Drezner, D. W. (2020). The Song Remains the Same: International Relations After COVID-19, International Organization, 74(1), pp. 18-35.

Gajić, A. S. (2015). Predlozi reforme sistema UN od strane svetskih federalista i kosmopolitskih demokrata [Proposals for reform of the UN system by world federalists and cosmopolitan democrats], in: Ž. Novičić, A. Đukanović (Eds.), Sedamdeset godina Ujedinjenih nacija - pogled iz Srbije [Seventy years of the 
United Nations: a view from Serbia] (32-56). Beograd, Institut za međunarodnu politiku i privredu.

Gordanić, J. (2015). Relation between the UN General Assembly and Security Council as an aspect of UN Reform, The Review of International Affairs, LXVI(1160), pp. 50-65.

Gould, M., Rablen, M. D. (2017). Reform of the United Nations Security Council: equity and efficiency. Public Choice, 173, pp. 145-168. doi: https://doi.org/ 10.1007/s11127-017-0468-2.

Hosli, M. O., Moody, R., O’Donovan B., Kaniovski S., Little, A. C. H. (2011). Squaring the circle? Collective and distributive effects of United Nations Security Council reform, The review of International Organizations, 6, pp. 163-187.

Kelly, M. J. (2000). U.N. Security Council Permanent Membership: New Proposal for a Twenty-First Century Council, Seton Hall Law Review, 31(2), pp. 319-399.

Krivokapić, B. (2015). Prvih 70 godina Ujedinjenih nacija u svetlu načela iz člana 2 Povelje UN [The first seventy years of the United Nations in light of the Article 2 of the UN Charter], in: Ž. Novičić, A. Đukanović (Eds.), Sedamdeset godina Ujedinjenih nacija-pogled iz Srbije [Seventy years of the United Nations: a view from Serbia] (9-31). Beograd, Institut za međunarodnu politiku i privredu.

Mälkso, L. (2010). Great Powers then and now: Security Council reform and responses to threats to peace and security, in: P. Danchin, H. Fischer (Eds.), United Nations Reform and the New Collective Security (pp. 94-114). Cambridge, Cambridge University Press.

Mingst, K. A., Karns, M. P., Lyion, A. J. (2017). The United Nations in the $21^{\text {st }}$ Century. New York, London, Routledge.

Negri, S. (2021). Introductory Note to United Nations Security Council Resolution 2532. International Legal Materials, 60(1), pp. 24-29. doi: https://doi.org/10. 1017/ilm.2020.63.

O'Rourke, C. (2020). International Law, COVID-19 and Feminist Engagement with the United Nations Security Council: The End of the Affair? Feminist Legal Studies, 28, pp. 321-328. doi: https://doi.org/10.1007/s10691-020-09440-4.

Özler, Ş. I. (2020). The United Nations at Seventy-Five: Passing the COVID Test? Ethics \& International Affairs, 34(4), pp. 445-456. doi: 10.1017/S0892679420000568.

Patrick, S. (2020). When the system fails, Foreign Affairs, 99 (4), pp. 40-51.

Pavone, I. R. (2021). Security Council Resolution 2532 (2020) on COVID-19: A Missed Opportunity? ESIL Reflections, 9(5), retrieved from https://esil-sedi.eu/wpcontent/uploads/2021/02/ESIL-Reflection-Pavone.pdf. Accessed 20 May 2021. 
Pobjie, E. (2020, July 27). Covid-19 as a threat to international peace and security: The role of the UN Security Council in addressing the pandemic, retrieved from https://www.ejiltalk.org/covid-19-as-a-threat-to-international-peace-andsecurity-the-role-of-the-un-security-council-in-addressing-the-pandemic/. Accessed 20 May 2021.

Schlein, L. (2021, January 8). UN Survery Reveals a Deeply Polarized World. Voice of America, retrieved from https://www.voanews.com/science-health/un-surveyreveals-deeply-polarized-world. Accessed 21 May 2021.

Security Council Report. (2021). The UN Security Council and Climate Change, retrieved from https://www.securitycouncilreport.org/atf/cf/\%7B65BFCF9B6D27-4E9C-8CD3-CF6E4FF96FF9\%7D/climate_security_2021.pdf. Accessed 2 August 2021.

Security Council. (2000). Resolution 1308 (2000) adopted by the Security Council at its $4172^{\text {nd }}$ meeting on 17 July 2000 , retrieved from https://digitallibrary. un.org/record/418823. Accessed 23 April 2021.

Security Council. (2014). Resolution 2177 (2014) adopted by the Security Council at its $7268^{\text {th }}$ meeting on 18 September 2014, retrieved from https://undocs.org/ S/RES/2177(2014). Accessed 23 April 2021.

Security Council. (2020). Resolution 2532 (2020) adopted by the Security Council on 1 July 2020, retrieved from https://undocs.org/en/S/RES/2532(2020). Accessed 4 May 2021.

Sekalala, S., Williams, C. R., Meier, B. M. (2021). Global Health Governance through the UN Security Council: Health Security vs. Human Rights?, retrieved from https://dx.doi.org/10.2139/ssrn.3785714.

Tharoor, S. (2011). Security Council Reform: Past, Present and Future, Ethics \& International Affairs, 25(4), pp. 397-406.

United Nations Charter. (1945), retrieved from https://www.un.org/en/about-us/uncharter/full-text. Accessed 3 August 2021.

United Nations Secretary-General. (2020, April 9). Secretary-General's remarks to the Security Council on the COVID-19 Pandemic (as delivered), retrieved from https://www.un.org/sg/en/content/sg/statement/2020-04-09/secretarygenerals-remarks-the-security-council-the-covid-19-pandemic-delivered. Accessed 20 May 2021.

Winther, B. Z. (2020). A Review of the Academic Debate about United Nations Security Council Reform, The Chinese Journal of Global Governance, 6, pp. 71-101. 